\title{
Magdalena Kuran*
}

(iD) https://orcid.org/0000-0001-6815-0011

\section{Twórczość dominikaniana Gabriela Zawieszki. Początki konceptyzmu w polskim kaznodziejstwie}

Gabriel Zawieszko (?-1649), podpisujący się jako Gabriel Leopolita, to jeden z wielu staropolskich kaznodziejów, których spuścizna czeka jeszcze na szczegółowe opracowanie. Ostatnim, który dorobkowi Zawieszki poświęcił nieco uwagi, był ks. Alojzy Jougan, wybitny homiletyk i historyk Kościoła. W swej ciągle ważnej dla dziejów polskiej wymowy kościelnej pracy Homilie polskie od czasów najdawniejszych po dobę obecna (1902), docenił „czystość nauk moralnych, żywość opisów” i „siłę wyrażeń” pisarstwa Leopolity'. Jednak nie zabrakło też uwag krytycznych, zwłaszcza gdy rzecz dotyczyła stylu, z powodu którego: „zyskuje wprawdzie oryginalność autora, ale cierpi poczucie estetyczne, a często i godność kazalnicy katolickiej"2. Styl Zawieszki charakteryzował szczegółowiej następująco:

Ulegając prądowi wieku, a raczej przywarom słuchaczy, Zawieszko lubi błyszczeć często wyskokami dowcipu, przytacza „uczone fraszki”, aluzyje, dziwaczne przypowieści (tzw. „curiosa”), wpada też często w przesadę, jakkolwiek znać wszędzie, że nie silił się o popisy, nie gromadził tych szczegółów dla czczej gadaniny, lecz dla lepszego wyjaśnienia rzeczy ${ }^{3}$.

* Dr, Uniwersytet Łódzki, Wydział Filologiczny, Instytut Filologii Polskiej i Logopedii, Zakład Dydaktyki Języka i Literatury Polskiej, ul. Pomorska 171/173, 90-236 Łódź; e-mail: magdalena.kuran@uni.lodz.pl

1 A. Jougan, Homilie polskie od czasów najdawniejszych po dobę obecna. Szkice bibliograficzne i krytyczne, Drukarnia katolicka Józefa Chęcińskiego, Lwów 1902, s. 195-196.

2 Tamże, s. 195.

3 Tamże, s. 195-196. 
Spostrzeżenia Jougana są celne (choć tylko tam, gdzie pozbawione oceniających epitetów), a jednocześnie, rzec by można, że ich autor tak surowo ocenił kaznodziejski dorobek Zawieszki, sam „ulegając prądowi wieku” niezwykle krytycznie odnoszącego się do specyfiki barokowej poetyki. Jougan zidentyfikował, nazwał i poddał krytyce pewne cechy barokowego stylu Leopolity. Trzeba też przyznać, że oddał sprawiedliwość kaznodziei, podkreślając, że celem ich użycia była nie „czcza gadanina", lecz chęć dotarcia do istoty rzeczy i jej wyjaśnienia.

Jeszcze jedno zdanie Jougana dotyczące kazań Zawieszki warte jest w tym kontekście przywołania: „Jednak obok licznych udatnych ustępów znamionują je równocześnie okazy psującego się ju ż wówczas [podkr. - M.K.] smaku estetycznego"4. W sądzie tym homiletyk właśnie u Zawieszki dostrzegł początki nowych zjawisk, które zaczęły zachodzić w polskim kaznodziejstwie pod koniec drugiego dwudziestolecia XVII w. I z tym sądem przyjdzie się zgodzić. Różnica dotyczy oceny tej zmiany.

Gabriel Zawieszko (? - 1649) urodził się we Lwowie, tam też kształcił się i wstąpił do zakonu dominikanów. Wiadomo, że był profesorem w tamtejszym konwencie przy klasztorze Bożego Ciała (w latach 1598-1604) . Jest też ślad, że w 1599 r. był przeorem klasztoru we Włodzimierzu (wtedy należącym do prowincji ruskiej)6. Około r. 1604 był wikarym generalnym kongregacji ruskiej’. W 1608 r. opuścił ją i - jak pisze historyk zakonu - „uciekł stamtąd do prowincji polskiej”. Był to czas niezwykle ostrych sporów i napięć w polskich prowincjach dominikańskich? Wiązało się to m.in. $\mathrm{z}$ wyznaczeniem nowych ich granic (w miejsce tych powstałych jeszcze w średniowieczu) oraz z wyodrębnianiem nowych kongregacji, z których potem utworzono prowincje ${ }^{10}$. Wskutek sporów i zmian organizacyjnych ośrodek lwowski w ciągu kilkunastu lat kilka razy zmieniał swą przynależnośćn ${ }^{11}$ To po

4 Tamże, s. 195.

5 R. Świętochowski, Szkolnictwo teologiczne dominikanów, w: Dzieje teologii katolickiej w Polsce, red. M. Rechowicz, t. 2: Od odrodzenia do oświecenia, cz. 2: Teologia neoscholastyczna i jej rozwój w akademiach i szkołach zakonnych, Wydawnictwo Towarzystwa Naukowego KUL, Lublin 1975, s. 240.

6 Zob. Tamże, s. 282 (tu mowa o kontaktach, jakie nawiązał Zawieszko jako przeor we Włodzimierzu z hierarchią Kościoła prawosławnego).

7 S. Barącz, Rys dziejów zakonu kaznodziejskiego w Polsce, t. 2, Nakładem W. Manieckiego, Lwów 1861, s. 160. Terminu „wikary generalny” użył S. Barącz. To termin historyczny, współcześnie zastąpiony przez wikariusza generalnego, tj. osobę wyznaczoną przez generała zakonu na jego pełnomocnika w prowincji.

8 R. Świętochowski, dz. cyt., s. 282.

9 J. Kłoczowski, Wielki zakon XVII-wiecznej Rzeczypospolitej u progu swego rozwoju. Dominikanie polscy w świetle wizytacji generalnej z lat 1617-19, „Nasza Przeszłość” 1973, t. 39, s. 106. Autor określit je jako ostre walki wewnątrzzakonne.

10 Szczegółowo ten wieloletni spór opisał R. Świętochowski, Początki dominikańskiej prowincji ruskiej (1596-1602), „Prawo Kanoniczne” 1980, t. 23, nr 1-2, s. 52-86.

11 Zob. J. Kłoczowski, dz. cyt., s. 106-107, 144 (mapa 1, na której widać zmiany granic prowincji). 
przybyciu do prowincji małopolskiej, jak twierdzi historyk zakonu Robert Świętochowski, Zawieszko miał rozwinąć aktywność pisarską ${ }^{12}$. Jego pobyt w niej wymaga jednak dokładniejszych badań. Dotychczasowe ustalenia są bardzo enigmatyczne. Sprowadzają się w gruncie rzeczy do stwierdzenia, że się do niej przeniósł. Wiadomo na pewno, że wszystkie prace Zawieszki (z wyjątkiem jednej to zbiory kazań) ukazały się na przestrzeni lat 1611-1619, a wydane zostały we Lwowie. Leopolita osiągnął znaczącą pozycję w zakonie, pełnił bowiem funkcję prowincjała. $\mathrm{W}$ aprobacji do jednego $\mathrm{z}$ jego zbiorów kazań datowanej na czerwiec 1617 r. nazwany został z kolei kaznodzieją generalnym zakonu (praedicator generalis) ${ }^{13}$. Czas jego aktywności w zakonie pozwolił mu zetknąć się z dominikańskimi teologami tej miary, co Antonin z Przemyśla (?-1619; także wychowanek lwowskiego konwentu, działający w prowincji ruskiej) czy Seweryn Lubomlczyk (1532-1612; związany mocno z Krakowem i tamtejszym klasztorem). Obaj byli zarazem bardzo mocno zaangażowani w spór między prowincjami oraz walkę frakcji tzw. krakowskiej i lwowskiej ${ }^{14}$. Zawieszko zmarł w $1649 \mathrm{r}$. w domu zakonnym prowincji polskiej w Samborze. Kazanie na jego pogrzebie wygłosił prefekt kolegium łuckiego, jezuita Jan Płocki ${ }^{15}$. Opinia w zakonie, która po nim pozostała, potwierdzała sławę, jaką przyniosła mu wymowa kaznodziejska, ascetyczny tryb życia, który prowadził, oraz świątobliwa śmierć16.

Mimo bardzo ostrych sporów między ośrodkami krakowskim i lwowskim, Zawieszko, który ostatecznie przeszedł do prowincji małopolskiej, wszystkie swoje prace wydał we Lwowie w drukarni na Przedmieściu Jaworowskim przy kościele

12 R. Świętochowski, Szkolnictwo teologiczne dominikanów, s. 282.

13 Aprobacja ta znajduje się w zbiorze G. Leopolita [Zawieszo], Oratorium pałaczu duchownego, Na Przedmieściu Jaworowskim przy Kościele Mikołaja Ś. w drukarni Jana Szeligi [Jaworów] 1619, k. ) (ij.

Franciszek Maksymilian Sobieszczański, autor biogramu Zawieszki w Encyklopedii powszechnej, podał też informację, że był Leopolita „kaznodzieją w kościele krakowskim Panny Maryi" (Encyklopedia powszechna, Warszawa 1864, t. 16, s. 896). Nigdzie więcej jej nie znalazłam. Jeśli przyjąć, że chodziło o kościół Mariacki, to informacji tej nie potwierdzają ustalenia Zbigniewa Barana, który odtworzył listę kolejnych zakonnych kaznodziejów kościoła Wniebowzięcia Najświętszej Maryi Panny (zob. Z. Baran, Kaznodzieje zakonni kościoła Mariackiego w Krakowie w latach 1594-1772, „Analecta Cracoviensia. Studia Philosophica - Theologica - luridica” 1989-1990, t. 21-23, s. 325-351).

14 Sytuację tę opisuje J. Kłoczowski, Wielki zakon XVII-wiecznej Rzeczypospolitej u progu swego rozwoju, [w:] tenże, Polska prowincja dominikańska w średniowieczu i Rzeczypospolitej Obojga (Wielu) Narodów, W Drodze, Poznań 2008, s. 120-125 oraz R. Świętochowski, Początki dominikańskiej prowincji..., s. 53-57, 79-83.

15 S. Barącz, dz. cyt., t. 2, s. 160.

16 F. Nowowieyski, Phoenix decoris et ornamenti, provinciae Poloniae, S[ancti] Ordinis Praedicatorum [...] redivivus in magnanimis viris, sanctitate vitae, scientiae et eruditione [...], Drukarnia Akademicka, Posnaniae 1752, s. 83. 
św. Mikołaja" ${ }^{17}$. Jego dorobek obejmuje kazania zebrane w tematycznych zbiorach. Trzy z nich związane są z tematem męki i zmartwychwstania Pańskiego -Księgi ćwiczenia chrześcijańskiego $(1611)^{18}$, Historyja o Jonaszu dla rozmyślania nadroższej Męki Pana Jezusowej (1618) ${ }^{19}$ oraz Wąż miedziany abo rozmyślanie nadroższej Męki Syna Bożego $(1618)^{20}$. Kolejne, to wykład słów Modlitwy Pańskiej - Oratorium pałaczu duchownego (1619) ${ }^{21}$; następne - opis życia, nawrócenia i pokuty św. Marii Magdaleny - Zwierciadło pokutujących z przykładów św. Marii Magdaleny uczynionych (1618) ${ }^{22}$, w końcu zbiór pt. Przysmaki duchowne, gorczyca i kwas (1619) ${ }^{23}$, w którym to tytułowe gorczyca i kwas stały się symbolicznymi narzędziami do refleksji o sposobach osiągnięcia Królestwa Bożego. Oprócz kazań Zawieszko wydał też łaciński minitraktat pt. Iustus iudex ex iustissimi iudicis Jesu Christi, omnibus iudicibus christianis, ad imitandum propositus (1615; 1618; dedykowany sędziemu Kasprowi Chążyńskiemu) ${ }^{24}$. Przedstawił w nim Chrystusa jako doskonały wzór dla wszystkich posiadających władzę sądzenia. Jerzy Bajda, badacz dziejów teologii moralnej, zaliczył dzieło do traktatów filozoficzno-etycznych, należących do nurtu humanistycznego ${ }^{25}$.

Pierwszą wydaną pracą Zawieszki był zbiór kazań Księgi ćwiczenia chrześcijańskiego z 1611 r. W r. 1615 wydał traktacik Iustus iudex, wznowiony w 1618 r. Pozostałe zaś pięć zbiorów kazań ukazało się w ciągu zaledwie dwóch lat (1618-1619). Wielce prawdopodobne, iż podał Zawieszko do druku kazania napisane dużo wcześniej. Pewnym tropem są aprobacje ze zbioru Oratorium pałaczu duchownego (1619). Mają one daty z czerwca 1617 r. Co warte odnotowania, tylko ta praca Leopolity je

17 Te wydane w latach 1618-1619 (a więc większość) dodatkowo posiadają informację, iż była to wówczas drukarnia Jana Szeligi, wcześniej drukującego w Krakowie.

18 G. Leopolita [Zawieszko], Księgi ćwiczenia chrześcijańskiego, Na Przedmieściu Jaworowskiem u S. Mikołaja [Jaworów] 1611.

19 Tenże, Historyja o Jonaszu dla rozmyślania nadroższej Męki Pana Jezusowej, Jan Szeliga, Lwów 1618.

20 Tenże, Wą̇ miedziany albo rozmyślanie nadroższej Męki Syna Bożego z wizerunku węża miedzianego, Jan Szeliga, Lwów 1618.

21 Tenże, Oratorium pałaczu duchownego, Na Przedmieściu Jaworowskim przy Kościele św. Mikołaja [Jaworów] 1619.

22 Tenże, Źwierciadło pokutujących. Z przykładów Ś[więtej] M[arii] Magdaleny uczynione. Nie rozpaczajcie wy, co więc Boga gniewacie, [Jan Szeliga], Lwów 1618.

23 Tenże, Przysmaki duchowne, gorczyca i kwas, Na Przedmieściu Jaworowskiem u Ś[w]. Mikołaja [Jaworów] 1619.

24 Tenże, lustus iudex ex iustissimi iudicis Jesu Christi, omnibus iudicibus christianis, ad imitandum propositus, In suburbio Jaworoviensi, ad Sanctum Nicolaum [Leopolis] 1615 (wyd. 2, Leopolis 1618).

25 J. Bajda, Poczatki teologii kazuistycznej w Europie i w Polsce, w: Dzieje teologii katolickiej w Polsce, red. M. Rechowicz, t. 2: Od odrodzenia do oświecenia, cz. 1: Teologia humanistyczna, Wydawnictwo Towarzystwa Naukowego KUL, Lublin 1975, s. 277-278. 
posiada. Ramy wydawnicze pozostałych ograniczają się do listów dedykacyjnych (wszystkie), wierszy na herby adresatów (za wyjątkiem Iustus iudex; tutaj tyko rycina przedstawiająca herb). W jednym przypadku jest też list do czytelników (Przysmaki duchowne; Do Czytelnika nabożnego). Warto też zwrócić uwagę, że w aprobacji do Oratorium znajdujemy następującą frazę: „censui opus intitulatum Palatium Spirituale, seusermones supra festa et Dominica totius anni [podkr. - M.K.] posse mandari praelo"26. Wyróżnioną formułę stosowano wobec zbiorów kazań obejmujących cały rok kościelny. U Zawieszki odnosi się ona do dwudziestu czterech kazań na wybrane dni świąteczne (przypadające w niedziele i w inne dni tygodnia). Być może sformułowanie „sermones... totius anni” przyczyniło się do tego, że np. Adam Jocher ${ }^{27}$ czy Franciszek Siarczyński ${ }^{28}$ pisali o tym, iż Zawieszko był autorem postylli. Błąd ten sprostowany został w bibliografii Karola Estreichera ${ }^{29}$ oraz w Postyllografii polskiej Kazimierza Kolbuszewskiego ${ }^{30}$. Zbiory Zawieszki liczą od czterech do dwudziestu czterech kazań podporządkowanych jakiemuś świętu, postaci bądź idei.

Wszystkie tytuły dzieł Leopolity mają charakter konceptystyczny, choć nie w sposób tak oczywisty, jak w innych dziełach dojrzałego baroku. Tytuły nie są też tak rozbudowane jak te późniejsze (zajmujące nieraz całą stronę; w postaci zdania wielokrotnie złożonego ${ }^{31}$. Tytuły barokowych kazań pogrzebowych poddał analizie Marek Skwara; podjął próbę ich opisu i systematyki. Jednak tutaj mamy do czynienia ze zbiorami, a te, przynajmniej częściowo, rządzą się innym prawami niż tytuły pojedynczych kazań. Znaczenie ma też to, że są to kazania niedzielne i świąteczne, a nie okolicznościowe. Te okolicznościowe, np. pogrzebowe, $\mathrm{z}$ racji przynależności do generis demonstrativi naturalnie predestynowane były do szczególnych zabiegów amplifikacyjnych, wśród których koncept wyrażony w tytule i rozwinięty w tekście zajmował miejsce szczególne. Kazania na niedziele i święta, związane z rokiem liturgicznym, były nieco mniej podatne na takie zabiegi.

Na nowy sposób formułowania tytułów nałożyły się przynajmniej dwa zjawiska. Pierwsze - teologiczne - to powrót w egzegezie dominacji sensu duchowego;

26 G. Leopolita [Zawieszko], Oratorium pałaczu duchownego, k. ) (ij. $_{\text {. }}$

27 A. Jocher, Obraz bibliograficzno-historyczny literatury i nauk w Polsce od wprowadzenia do niej druku po rok 1830 włącznie, t. 2, Drukarnia Uniwersytetu Jagiellońskiego, Wilno 1842, s. 378.

28 F. Siarczyński, Obraz wieku panowania Zygmunta III króla polskiego i szwedzkiego [...], cz. 2, Józef Schnayder, Lwów 1828, s. 359.

29 K. Estreicher, Bibliografia polska, t. 21, Drukarnia Uniwersytetu Jagiellońskiego, Kraków 1906, s. 182.

30 K. Kolbuszewski, Postyllografia polska XVI i XVII wieku, Nakładem Polskiej Akademii Umiejętności, Kraków 1921, s. 272-273.

31 M. Skwara, O tytułach polskich kazań pogrzebowych z XVII wieku, w: Dzieło literackie i ksiażka w kulturze, red. I. Opacki przy współudziale B. Mazurkowej, Wydawnictwo Uniwersytetu Śląskiego, Katowice 2002, s. 436. 
drugie - retoryczne - upodobanie do wypowiedzi o charakterze konceptystycznym. Sens duchowy i konceptyzm mogły dochodzić do głosu i realizować się na każdym poziomie kaznodziejskiej wypowiedzi - argumentu, pojedynczego kazania i całego zbioru. W przypadku Zawieszki tylko w jednym ze zbiorów (Oratorium pałaczu duchownego) metafora zawarta w tytule nie ma wpływu na kompozycję zbioru, ani nie jest w nim rozwijana. Jej rozwikłanie pozostawił kaznodzieja czytelnikom. Bezpośrednio do niej odniósł się za to jeden z cenzorów, Joachim Morochowski, biskup włodzimierski, który w aprobacji podjął metaforę i podał jedno z możliwych jej wyłożeń: „Palatium hoc spirituale, ac misticum Dei tabernaculum [...] ex praetiosis Divini dogmatis gemmis constructum" ${ }^{32}$. Kolejne słowa bądź frazy Modlitwy Pańskiej rozpisane na dwadzieścia cztery kazania i w nich zinterpretowane określił biskup mianem szlachetnych kamieni, z których za sprawą Leopolity wzniesiony został duchowy pałac. Zawieszkę przyrównał Morochowski do starotestamentowego Besaleela. Był to utalentowany rzemieślnik, któremu Bóg przez Mojżesza powierzył wykonanie przybytku i jego wyposażenia ${ }^{33}$.

W Zwierciadle pokutujących metaforyczny tytuł sięga głębiej. Cykl dziesięciu kazań, kreślących na podstawie historii Marii z Magdali obraz doskonałej pokuty i pokutującego, przypomina nieco speculum, formę literatury parenetycznej. Święta staje się doskonałym wcieleniem nawróconego grzesznika, modelowo realizującego pokutę, aby odkupić swe grzechy. Zarazem w pierwszych trzech kazaniach eksploruje Leopolita wielorako pojęcia związane z materialnym zwierciadłem, jak i zwierciadłem-wizerunkiem. W kazaniu pierwszym wychodząc od lustra, bez którego „żadna rozkosznica się obejść nie może" ${ }^{\text {"34 }}$, prezentuje trzy »Zwierciadła fałszywe«: pożądliwości ciała, pożądliwości oczu i pychy żywota. Przeciwstawił je „zwierciadłu prawdziwemu”, które pokazuje wszystkie przymioty odbijanego obiektu, zarówno te piękne, jak i szpetne. W kazaniu drugim znajdujemy opis Chrystusa jako „zwierciadła bez zmazy”. W końcu w kazaniu trzecim to dom Szymona Trędowatego, w którym Magdalena spotyka Jezusa, staje się „wizerunkiem wszystkiego świata"35.

W kolejnych czterech zbiorach Zawieszki tytułowa metafora jeszcze głębiej wnika w strukturę tekstów. W Historyi o Jonaszu dla rozmyślania nadroższej Męki Pana Jezusowej oraz Wężu miedzianym abo rozmyślaniu nadroższej Męki Syna Bo$\dot{z}$ ego Leopolita wykorzystał sens alegoryczny (jedną z trzech odmian sensu duchowego) Pisma Świętego, w którym to osoby, rzeczy i wydarzenia starotestamentowe interpretowane są jako zapowiedzi wydarzeń z Nowego Testamentu. W pierwszym

32 G. Leopolita [Zawieszko], Oratorium pałaczu duchownego, k. [)(jv]. Przekład: Ten duchowy pałac i mistyczny przybytek Boga [...] wzniesiony został z wybornych kamieni boskich nauk.

33 Zob. Wj 31, 1-11.

34 G. Leopolita [Zawieszko], Zwierciadło pokutujacych, s. 3.

35 Tamże, s. 48. 
zbiorze kolejne kazania na święta Chrystusowe podporządkowane zostały chronologii wydarzeń z życia starotestamentowego Jonasza, który staje się figurą umęczonego i zmartwychwstałego Jezusa.

W figuratywnym czytaniu wydarzeń i postaci starotestamentowych szczególne miejsce $w$ alegorycznej egzegezie zajmował Chrystus jako antytyp, tj. spełnienie starotestamentowego typu. W siedemnasto- i osiemnastowiecznych kazaniach Chrystus bywał Jonaszem, Adamem, Ablem, Izaakiem, Jakubem, Józefem, Mojżeszem, Aaronem, Dawidem, Oblubieńcem, Abrahamem, Salomonem, Eliaszem, Jeremiaszem, Samsonem, Ezechielem, Micheaszem, Tobiaszem czy Hiobem ${ }^{36}$. Spośród tych postaci Jonasz należał do najczęściej wykorzystywanych typów - także za sprawą samych Ewangelii. U Mateusza znajdujemy słowa: „Albowiem jako był Jonasz w brzuchu wieloryba trzy dni i trzy noce, tak będzie Syn Człowieczy w sercu ziemie trzy dni i trzy nocy" (Mt 12, 40 ${ }^{37}$.

Widowiskowa scena $\mathrm{z}$ wielorybem (piscis grandis) ${ }^{38}$ połykającym Jonasza była chętnie wykorzystywana w grobach Pańskich, czego świadectwa zostawili choćby Jędrzej Kitowicz czy Stefan Poniński, opisujący takowe ${ }^{39}$. Postać Jonasza wydostającego się z wnętrzności ogromnej ryby przemawiać musiała do wyobraźni bardzo mocno. W okresie baroku powstały ambony $\mathrm{w}$ kształcie wieloryba ${ }^{40}$, $\mathrm{z}$ którego to

36 Wszystkie te postaci jako starotestamentowe figury osobowe Chrystusa zostały przeze mnie wskazane w konkretnych kazaniach w: M. Kuran, Polska religijność pasyjna w świetle kazań wielkopiątkowych (1702-1732) z biblioteki klasztoru reformatów w Zakliczynie, w: Miscellanea literackie i teatralne (od Kochanowskiego do Mrożka). Profesorowi Janowi Okoniowi przez przyjaciół i uczniów na 70. urodziny zebrane, red. K. Płachcińska i M. Kuran, cz. 1, Wydawnictwo Uniwersytetu Łódzkiego, Łódź 2010, s. 452-453.

37 Wszystkie biblijne cytaty za J. Wujek, Biblia w przekładzie księdza Jakuba Wujka z 1599 r. Transkrypcja typu "B” oryginalnego tekstu z XVI w. i wstępy ks. J. Frankowski, Warszawa 2000, Oficyna Wydawnicza "Vocatio".

38 Stosuje się tu konsekwentnie używany przez Zawieszkę termin „wieloryb”. Funkcjonował on wówczas naprzemiennie z określeniem „wielka ryba”. W Wulgacie w Księdze Jonasza jest piscis grandis, zaś u Mateusza $(12,40)$ cetos/cetus oznaczający wszelką wielką rybę morską (np. wieloryba, delfina).

39 W wielkopiątkowym kazaniu Poniński opisał grób Pański przedstawiający wzburzone morze, a na nim wieloryba połykającego Jonasza z napisem nad grobem "Sicut suit Jonas in ventre ceti, sic Filius Hominis" (S. Poniński, Król nieba i ziemi Chrystus Zbawiciel kazaniami na uroczyste swoje święta [...] wysławiony, W drukarni Collegium Societatis Jesu, Poznań 1725, s. 201). Z kolei Kitowicz opisywał: „Groby robione były w formę rozmaitą, stosowaną do jakiej historii, z Pisma Świętego Starego bądź Nowego Testamentu wyjętej. Np. reprezentowały Abrahama patriarchę, syna swego Izaaka na ofiarę Bogu zabić chcącego, albo Józefa patriarchę od braci swoich do studni wpuszczanego, albo Daniela proroka w jamie między Iwami zostającego, albo Jonasza, którego wieloryb połyka paszczęką swoją, i tym podobnie" (J. Kitowicz, Opis obyczajów za panowania Augusta III, wstęp M. Dernałowicz, PIW, Warszawa 1985, s. 47).

40 Zobaczyć taką można np. w kościele św. Piotra i Pawła w Dusznikach-Zdroju czy w Dobroszowie na Dolnym Śląsku w kościele św. Jadwigi. 
paszczy wyłaniający się kaznodzieja jawił się jako Jonasz posłany przez Boga, ale i trochę jako uosobienie Chrystusa wychodzącego z grobu. Jednak to, co zrobił Zawieszko, to nie metonimia ani nawet rozbudowane podobieństwo, to przełożenie starotestamentowej historii w każdym możliwym szczególe na opowieść o męce Chrystusa. Mamy 132 strony opowieści o Chrystusie-Jonaszu. Znaczenie i duchową wykładnię zyskują szczegóły, zdawać by się mogło, bez znaczenia. I tak np. piaszczysty brzeg morski oddaje charakter Chrystusowego człowieczeństwa (znaczenie duchowe mają choćby jego sypkość czy wilgotność):

A iż człowieczeństwo Chrystusowe może być nazwane piaskiem na brzegu morskim leżącym, łacno to obaczyć możemy z własnych słów Pana Boga wszechmogącego, który ojcu wszystkich wierzących obiecał, iż potomstwo jego miało być jako piasek morski i Hieremijasz prorok wielkość synów izraelskich przyrównywa do piasku na brzegu morskim będącego [...]. Tedyć idzie za tym, że ten nazaczniejszy potomek Abrahamów, w którym wszystkie narody wszystkiego świata dostąpili błogosławieństwa, jest nabliższym piaskiem przy samych wodach morskich leżącym. Dalej od wody morskiej leży inszy piasek, onych świętych synów izraelskich, którzy cokolwiek cierpieli [...], co się miało w męce Chrystusowej wypełnić całkiem ${ }^{41}$.

Właściwości przybrzeżnego piasku pozwalają mu dookreślić odkupieńczą rolę męki Chrystusa. Niezliczona ilość ziaren piasku dowodzi:

Iż jako piasek morski przechodzi wszelką liczbę i wszelki rachunek, i wszelką wagę, i wszystkę miarę, tak zasługi niewinnej męki i nadroższej śmierci jego daleko większą obfitością przechodzą wszystkie rozumy, wszystkich rachmistrzów, wszystkich ważnych, wszystkich mierników tak dalece, że chociajby na jedno miejsce zebrane były wszystkie [...], nie mogłyby zmierzać nieprzeliczonych i nieporachowanych zasług niewinnej męki Zbawiciela naszego ${ }^{42}$.

Wilgotność piasku pokazuje z kolei, iż zasługi męki „nigdy nie wysychają”, zaś jego sypkość dowodzi łatwości pozyskiwania łaski. Tak bowiem jak łatwo nabrać piasek do naczynia, tak i „zasługi Chrystusa Pana naszego kożdemu człowiekowi są sypkie i do łacnego nabrania sposobne"43.

Ten sposób przekładania historii proroka Jonasza na opis i teologiczny wykład męki Pańskiej charakterystyczny jest dla całego wywodu Zawieszki. Figuratywnego charakteru nabierają przedmioty (morze, okręt i gołębica), zjawiska (wiatr, głębokość morza i nudności podczas morskiej podróży), miejsca znane ze starote-

41 G. Leopolita [Zawieszko], Historyja o Jonaszu, s. 11-12.

42 Tamże, s. 17-18.

43 Tamże, s. 20-21. 
stamentowej opowieści (Niniwa, Joppen, Tars i Syjon ${ }^{44}$ ), a także postaci (dowódca okrętu i żeglarze) i ich działania (ucieczka Jonasza, żeglarze rzucający losy, śpiący Jonasz, wyrzucanie naczyń z okrętu). Przywołano tu zaledwie kilka przykładów z wieloelementowej symbolicznie opowieści o Jonaszu, która za sprawą duchowej interpretacji stała się wielowymiarową opowieścią o męce Chrystusa.

Z kolei w zbiorze Wąż miedziany albo rozmyślanie nadroższej Męki Syna Bożego $z$ wizerunku węża miedzianego rytm kazań wyznaczała starotestamentowa historia buntu Izraelitów przeciwko Mojżeszowi, za co Bóg zesłał na nich jadowite węże. Mojżesz wstawił się za ludem do Najwyższego. Na jego rozkaz sporządził miedzianego węża, umieścił go na palu, aby każdy ukąszony, który na niego spojrzy, mógł być uzdrowiony. Tym razem męka Pańska opowiedziana została poprzez historię wędrówki Żydów z Egiptu. Kolejnym kazaniom patronują pojawiające się podczas tej drogi rzeczy-znaki, które też przełożone zostały na kolejne etapy męki Pańskiej (np. palmy, pod którymi odbył się pierwszy spoczynek po wyjściu z Egiptu, posłużyły do opisu wydarzeń Niedzieli Palmowej; manna na pustyni - wieczerza Pańska - Wielki Czwartek; wąż miedziany - Chrystus wzniesiony na krzyżu -Wielki Piątek; wąż odnowiony ${ }^{45}$ - figura zmartwychwstania - poranek Wielkanocny). Podobnie jak w zbiorze wcześniejszym, każdy szczegół starotestamentowej opowieści mógł zyskać duchowe przełożenie na historię Jezusowej męki.

W zbiorze Przysmaki duchowne, gorczyca i kwas to nowotestamentowe przypowieści o ziarnie gorczycy i zaczynie posłużyły do skonstruowania zbioru. Kazania nie zostały przypisane do żadnych świąt czy uroczystości. Nośnikami sensu stały się tam nie tylko figury, które w tych przypowieściach znajdziemy: ziarno gorczycy, drzewo gorczyczne, ptaki niebieskie (3 kazania), kwas, trzy stągwie mąki, ale też młyn, który staje się logicznym dopełnieniem symboliki z drugiej przypowieści. Dał on kaznodziei możliwość poszerzenia krótkiej przypowieści-podobieństwa: „Podobne jest Królestwo Niebieskie kwasowi, który wziąwszy niewiasta, zakryła we trzy miary mąki, aż wszytka skwaśniała" (Mt, 13, 33). Kwas i trzy miary mąki posłużyły za symbole-drogowskazy dwóch kazań, młyn zaś trzech kolejnych.

Niezwykle ciekawy jest zresztą sposób opracowania tych trzech kazań. Noszą one kolejno tytuły: Młyn Pański na mąkę pospolitą, Młyn Pański na mąkę pytlowana, Młynek duchowy na skruszone serca. Pokazuje to możliwości, jakie dawało operowanie symbolami, jak poszerzało pola interpretacyjnego manewru kaznodziei. Sermones, których dyrektywę semantyczną stanowi „młyn”, zbudowane są na zasadzie swoistej symetrii. Pojedynczy symbol zamienia się w symbol rozwinięty, rozrasta się o kolejne symbole szczegółowe, które decydują o strukturze kaza-

44 Joppen we współczesnych tłumaczeniach Biblii to Jafa, zaś Tars to Tarszisz (Tartessos).

45 To nawiązanie do zniszczenia przez Ezechiasza węża miedzianego: „On to [...] połamał węża miedzianego, którego był uczynił Mojżesz, bo aż do onego czasu synowie Izraelowi palili mu kadzidło" $(2 \mathrm{Kr} 18,4)$. 
nia. Symetria polega na tym, że w każdym z nich symbol dominujący jest ten sam (młyn), te same są także symbole pomocnicze. Jednak w każdym z nich odnosi je Zawieszko do innej rzeczy. W pierwszym młyn to świat, w drugim - Kościół, w końcu w trzecim - sumienie człowieka. Symetrię tę uwidacznia tabela:

Tabela 1. Zestawienie motywów z trzech kazań ze zbioru Przysmaki duchowne, gorczyca i kwas: Młyn Pański na mąkę pospolitą, Młyn Pański na mąkę pytlowaną, Młynek duchowy na skruszone serca

\begin{tabular}{|c|c|c|c|}
\hline Symbole & $\begin{array}{l}\text { Młyn Pański na } \\
\text { mąkę pospolitą }\end{array}$ & $\begin{array}{c}\text { Młyn Pański na mąkę } \\
\text { pytlowaną }\end{array}$ & $\begin{array}{c}\text { Młynek duchowy na } \\
\text { skruszone serca }\end{array}$ \\
\hline młyn & świat & Kościół & sumienie człowieka \\
\hline koła młyńskie & sfery niebieskie & $\begin{array}{l}\text { powaga Kościoła } \\
\text { powszechnego }\end{array}$ & wolna wola \\
\hline kamień spodni & moc rodząca ziemi & Stary Zakon & bojaźń Boża \\
\hline kamień wierzchni & $\begin{array}{l}\text { błogosławieństwo } \\
\text { Boże }\end{array}$ & Nowy Zakon & Sąd Ostateczny \\
\hline $\begin{array}{l}\text { cztery siły } \\
\text { wprawiające młyn } \\
\text { w ruch: } \\
\text { woda } \\
\text { wiatr } \\
\text { zwierzęta } \\
\text { człowiek }\end{array}$ & $\begin{array}{l}\text { łzy pokutującego } \\
\text { szum modlitw } \\
\text { uczynki miłosierdzia } \\
\text { Samson-Chrystus }\end{array}$ & $\begin{array}{l}\text { wiedza o Bogu } \\
\text { duch Święty } \\
\text { apostołowie } \\
\text { biskupi i kapłani }\end{array}$ & $\begin{array}{l}\text { łzy pokuty i żalu } \\
\text { wzdychanie do Boga } \\
\text { emocje: chęć } \\
\text { pożądająca zbawienia } \\
\text { i gniew na swą } \\
\text { grzeszność } \\
\text { rozum }\end{array}$ \\
\hline trzy dzieże: & $\begin{array}{l}\text { odniesione do } \\
\text { chrześcijan: }\end{array}$ & $\begin{array}{l}\text { odniesione do sposobów } \\
\text { wykładania Pisma } \\
\text { Świętego: }\end{array}$ & $\begin{array}{l}\text { odniesione do } \\
\text { konkretnej osoby: }\end{array}$ \\
\hline 1 & $\begin{array}{l}\text { rozum } \\
\text { wola } \\
\text { pamięć }\end{array}$ & $\begin{array}{l}\text { alegoria } \\
\text { tropologia } \\
\text { anagogia }\end{array}$ & $\begin{array}{l}\text { wiara } \\
\text { nadzieja } \\
\text { miłość }\end{array}$ \\
\hline kwas & bojaźń Boża & - & umartwienie \\
\hline symbole dodatkowe & mąka zwykła & $\begin{array}{l}\text { mąka pytlowana, } \\
\text { młynarze }\end{array}$ & $\begin{array}{l}\text { rola, oracz, pszenica, } \\
\text { źdźbło, młocarnia }\end{array}$ \\
\hline
\end{tabular}

Oprac. Magdalena Kuran

W przypadku tego zbioru dostrzec też można potencjał duchowej interpretacji Pisma Świętego. Wynikała ona z nieograniczonej niemal możliwości poszerzania symbolu o kolejne elementy pozostające z nim w logicznym związku. Przykład ten 
pokazuje również, jak podatne na semantyczną wariantywność okazywały się być biblijne symbole oraz $\mathrm{w}$ jaki sposób można było tworzyć $\mathrm{z}$ nich wieloelementowe i wielostopniowe poetyckie niemal konstrukty. Kluczową rolę odgrywały tu kaznodziejska wyobraźnia, talent i biblijna erudycja.

Ostatni ze zbiorów Leopolity to Ksieggi ćwiczenia chrześcijańskiego. Gromadzi on zaledwie cztery kazania na, jak określił kaznodzieja, „tydzień święty” - od Niedzieli Palmowej, przez Wielki Czwartek, Wielki Piątek po Niedzielę Wielkanocną. Na stronie tytułowej znajdujemy słowa z Księgi Ezechiela: „Zjedz te księgi”. Opisane jest w niej widzenie proroka, w którym Bóg zwraca się do niego, mówiąc: "Otwórz usta twoje a jedz, co ja daję tobie. I ujźrzałem, ano ręka ściągniona ku mnie, w której były zwinione księgi. [...] I rzekł do mnie: synu człowieczy, cokolwiek najdziesz, zjedz; zjedz te księgi [...]. I otworzył usta moje i nakarmił mię onemi księgami” (Ez 2, 8-9; 3, 1-2).

Księga jako metafora wykorzystywana była w literaturze teologicznej powszechnie. Najpopularniejszą była Księga Natury, żywotna przynajmniej po oświecenie (co wnikliwie opisał Ernst Robert Curtius) ${ }^{46}$. Niemniej popularna jako metafora była Liber Scriptura. Odnoszono ją choćby do Maryi, która przedstawiana była jako najdoskonalsza książka spisana ręką Boga. Przykłady znajdziemy, np. u Jana Damascena, św. Bonawentury, św. Antoniego z Padwy. Z polskich kaznodziejów podejmowali ją Franciszek Rychłowski ${ }^{47}$ czy Antoni Węgrzynowicz ${ }^{48}$. Ten drugi w kazaniu wielkopiątkowym zastosował ją także do Chrystusa (Siedm pieczęci Ksiegi Barankowej to jest kazanie na Wielki Piatek ${ }^{49}$ ). U Zawieszki znajdujemy ten sam koncept. W liście dedykacyjnym pisał o Jezusie:

[...] na krzyżu przybity sam jest nadoskonalszemi księgami ćwiczenia chrześciańskiego, w którego jako w jedno króciuchne zebranie wbite są wszystkie Księgi Mojżeszowe i wszystkich proroków żydowskich i Sybil pogańskich, i wszystkie księgi

46 E. R. Curtius, Literatura europejska i łacińskie średniowiecze, przekł. i oprac. A. Borowski, Universitas, Kraków 1997, s. 326-333. Curtius pokazał, jak powszechne od średniowiecza aż po barok były „przenośnie książkowe” (s. 329) oraz w jakim kierunku ewoluowały.

47 F. Rychłowski, Kazania na święta Panny Przenaświętszej z różnych doktorów i autorów napisane, Kraków 1667, s. 8-14 [Na dzień Niepokalanego Poczęcia Panny Przenaświętszej kazanie wtóre]; 33-55 [trzy kazania Na dzień Narodzenia Panny Przenaświętszej]. Te same kazania znajdziemy jeszcze w powtórzonym wydaniu tego zbioru (Kraków 1677). Jedno z tych kazań zostało wydane i opracowane przez W. Pawlaka i B. Niebelską-Rajcę. Zob. F. Rychłowski, Na dzień Niepokalanego Poczęcia Panny Przenajświętszej kazanie wtóre (1667), oprac. W. Pawlak i B. Niebelska-Rajca, w: Umyst stateczny i w cnotach gruntowny. Prace edytorskie dedykowane pamięci Profesora Adama Karpińskiego, red. R. Grześkowiak, R. Krzywy, Wydział Polonistyki Uniwersytetu Warszawskiego, Warszawa 2012, „Studia o literaturze dawnej”, t. 1, s. 159-183.

48 A. Węgrzynowicz, Syllabus Marianus syllabarum consonantium alia discursus concionatorii in titulos B. V. Mariae a syllabis initiatos [...], Leopoli 1717, kol. 496-513.

49 Mistyczną księgą jest Chrystus w swej boskiej (księga pisana wewnątrz) i ludzkiej (księga pisana zewnątrz) naturze. Pieczęcie to boskie przymioty, które podczas męki i śmierci „zapieczętował", tj. ukrył, aby mogło się dokonać odkupienie. 
Ewangelistów, i Apostołów, i doktorów Kościoła Bożego, i wszystkie, które będą o nich pisane aż do samego skończenia świata. Pan Chrystus jest kompendium wszystkiego Pisma Świętego"50.

Kluczowe jest tu słowo „kompendium”. Tym razem wydarzenia, postaci, rzeczy, które Ewangelie opisują od wjazdu do Jerozolimy po Zmartwychwstanie, dają kaznodziei asumpt do wykładu podstawowych chrześcijańskich prawd. Centralne jest kazanie wielkopiątkowe (czterokrotnie dłuższe od pozostałych). Chrystus na krzyżu staje się „katedrą nawyższą”, z której uczy cnót niezbędnych do zbawienia. Konfrontuje Zawieszko na początku kolejne mądrościowe maksymy wzięte z filozofów, astrologów, geometrów, medyków, muzyków, prawników i pokazuje, jak mało są warte w zestawieniu z mądrością płynącą z krzyża („Chrystus ukrzyżowany uczynił z maksymy minimę”; s. 47). Na właściwy opis męki, od Ogrójca po śmierć, nałożony został wykład czterech cnót kardynalnych (roztropność, sprawiedliwość, umiarkowanie, męstwo), trzech cnót boskich (wiary, nadziei, miłości), ośmiu błogosławieństw, siedmiu uczynków miłosiernych oraz wykład „testamentu Pańskiego", jak nazwał ostatnie odnotowane w Ewangeliach słowa Jezusa wypowiedziane na krzyżu. Opis męki jest więc zarazem rodzajem katechizmu.

Wielki dominikański mistrz, św. Tomasz z Akwinu, miał mieć widzenie, w którym stanął przed nim św. Bonawentura. Tomasz zapytał go, skąd czerpie te wszystkie mądrości, o których pisze. Doktor seraficki odpowiedział, wskazując na ukrzyżowanego Chrystusa: „Ta jest jedyna księga moja, z tej się wszytkiego uczę" ${ }^{\text {. }}$. Z kolei św. Bonawentura w Hexameronie wyjaśniał, jak czytać Pismo, by przyniosło zbawienne skutki:

Bo podobnie jak Bóg połączył we wzajemnym stosunku zmysł smaku i pokarm, ponieważ dał pokarmowi smak, a zmysłowo zdolność rozróżniania i dzięki tym dwom elementom pokarm zostaje włączony w ciało, tak najpierw trzeba przyjąć Pismo Święte, potem powtarzając rozgryzać, a odtąd przyswajać, a wówczas staje się pokarmem duszy ${ }^{52}$.

Można rzec, że to mistyczny wykład wezwania z Księgi Ezechiela - „Zjedz te księgi” - wezwania, które posłużyło za motto zbioru Zawieszki.

Choć odniesień do przywołanych tu scen i słów św. Tomasza i św. Bonawentury w kazaniu nie ma, to pozwalają one dostrzec, $\mathrm{z}$ jakiej tradycji wyrastał i jaką

50 G. Leopolita [Zawieszko], Księgi ćwiczenia chrześcijańskiego, k. [a4v].

51 F. Rychłowski, Na dzień Niepokalanego Poczęcia Panny Przenajświętszej kazanie wtóre (1667), s. 14.

52 Św. Bonawentura z Bagnoregio, Konferencje o sześciu dniach stworzenia albo oświecenia Kościoła. Wydanie synoptyczne tekstu oryginalnego redakcji A oraz B z przekładem polskim, przekł., red. i wstęp A. Horowski, Wydawnictwo Serafin, Wydawnictwo Unum, Kraków 2008, s. 513. 
ścieżką teologiczną podążał Leopolita. W refleksji tych dwóch wielkich teologów, wielokrotnie przywoływanych $\mathrm{w}$ jego kazaniach, pojawiają się kwestie kluczowe dla zrozumienia sposobów uprawiania tego typu kaznodziejstwa. Oczywiście w skrócie i największym uproszczeniu: św. Bonawentura podjął i rozwinął pojęcie teologii symbolicznej (zaczerpnięte od Dionizego Areopagity), według której cała postrzegana zmysłowo rzeczywistość staje się znakiem Bożych tajemnic. To próba dostrzeżenia pewnej struktury symbolicznej czy wręcz symbolicznego systemu w różnych przejawach rzeczywistości i na różnych jej poziomach. Zastosowanie znajduje tu również idea, rozwinięta przez św. Tomasza, zwana analogia entis, w której poznanie Boga dokonuje się przez porównanie ze stworzeniem ${ }^{53}$. Oba pojęcia dopełnione zostają mistyczną interpretacją Pisma Świętego. To ważne, aby zrozumieć, gdzie jest źródło pozwalające teologom sięgać po „odległe” metafory, których efektem bywały - szczególnie z perspektywy współczesnego odbiorcy - „naciągane” alegorie ${ }^{54}$.

Na twórczość Zawieszki warto zwrócić szczególną uwagę, ponieważ wydaje się, iż był on pierwszym, który tak konsekwentnie w całej swojej twórczości dał świadectwo zmianie, jaka właśnie zachodziła na gruncie polskiego kaznodziejstwa. Sygnały pojawiały się już kilkadziesiąt lat wcześniej. Za takie można chyba uznać symptomy ze zbioru pt. Flores sermonum Mikołaja z Wilkowiecka (1586) ${ }^{55}$. Był to cykl sześciu kazań, bardzo rozbudowanych, przeznaczonych na pięć kolejnych niedziel po uroczystości Trójcy Świętej, przy czym na niedzielę piątą przypadały dwa. Właśnie to drugie jest w wymienionym kontekście najbardziej interesujące. Nosi tytuł: Eiusdem dominicae, spiritualis sive mystica Evangelii interpraetatio ${ }^{56}$ (Duchowe albo mistyczne tłumaczenie Ewangelii). Kazanie poświęcone jest roli i zadaniom kaznodziei, sposobom przepowiadania Słowa, odbiorcom i sposobom dotarcia do nich, ale, co tutaj najważniejsze, całe oparto na mistycznej interpretacji sceny z Ewangelii św. Łukasza (5, 1-11), w której Jezus wpierw naucza z łodzi, a potem pomaga Szymonowi i synom Zebedeusza napełnić sieci rybami, zapowia-

53 Zagadnienie analogii w filozofii i teologii jest niezwykle skomplikowane i wielowątkowe. Skrótowe przedstawienie zagadnienia analogii w filozofii klasycznej znajduje się w Encyklopedii katolickiej (M. Krapiec, Analogia: II. W filozofii klasycznej, w: Encyklopedia katolicka, t. 1, kol. 492-497). Tam też szczegółowa bibliografia.

54 Podjęłam tutaj myśl. J. Abramowskiej, która swoje spostrzeżenie odniosła do analogii konotacyjnej wykorzystywanej w biblijnej egzegezie: „Analogia konotacyjna morze wykorzystywać cechy definicyjne, lub nieistotne, drugorzędne. Ten ostatni przypadek przynosi często ciekawe, "odległe« metafory, albo dowolne, »naciągane" alegorie" [podkr. - M.K.]. J. Abramowska, Powtórzenia i wybory. Studia z tematologii i poetyki historycznej, Dom Wydawniczy Rebis, Poznań 1995, s. 57.

55 Mikołaj z Wilkowiecka, Flores sermonum in Evangelia Dominicalia post festum Sanctissimae Trinitatis [...], Matheus Gariuoliu, Cracoviae 1579.

56 Tamże, k. 315r-355v. 
dając, że odtąd będą łowić ludzi. Każdy z elementów tej sceny zyskuje duchową, rozbudowaną interpretację: morze, łódź, wiatr, fale, sieci, ryby i apostołowie-rybacy. Znaczenie imion tych ostatnich każe wnioskować o kolejnych niezbędnych cechach dobrego kaznodziei: Piotr - scientia, bo na niej opiera się przepowiadanie; Jakub - supplantator ${ }^{57}$, ten który oszukuje zło (supplantatio mali); Jan - Bóg jest łaskawy - łaska Boża jest bowiem niezbędna do dobrego przepowiadania, a przepowiadanie to zarazem głoszenie Bożej łaskawości, itd. ${ }^{58}$

Już sam tytuł pracy paulina - Flores sermonum - choć daleko mu jeszcze do rozbudowanych i wyszukanych metafor w tytułach zbiorów późniejszych, jednak wyróżnia się na tle współczesnych sobie, stricte technicznych i opisowych formul, które metaforami nie operowały. Tak mocne wyeksponowanie sensu duchowego w interpretacji Pisma Świętego, sposób skonstruowania tytułu zbioru kazań to zaledwie symptomy, ale niezwykle znaczące w porównaniu do ówczesnego katolickiego kaznodziejstwa w Polsce (vide Jakub Wujek, Piotr Skarga, Józef Wereszczyński).

Otwartym zagadnieniem pozostaje, co wpłynęło na kształt uprawianego przez Zawieszkę kaznodziejstwa. Pierwsza odpowiedź, jaka się nasuwa, to zakonna edukacja. Jednak na tle ówczesnych dominikańskich kaznodziejów jego twórczość się wyróżnia. Konsekwencja, z jaką wszystkie swoje zbiory podporządkował tytułowej metaforze, czyniąc z nich, a także z poszczególnych włączonych doń kazań konstrukty konceptystyczne, jest zadziwiająca i wówczas jeszcze odosobniona.

Wpływ na Zawieszkę mogły mieć prace i teoretyczne poglądy jego współbrata, wybitnego teologa, polemisty, prawnika i kaznodziei - Seweryna Lubomlczyka (zm. 1612). Wprawdzie nie zachowały się żadne kazania Seweryna z Lubomli. Musiał jednak być wybitnym mówcą, skoro pełnił funkcję kaznodziei w krakowskim klasztorze dominikanów i, co szczególnie istotne, w kościele Mariackim. Jest pierwszym w okresie potrydenckim znanym z imienia kaznodzieją zakonnym w tej renomowanej placówce ${ }^{59}$. To, co po sobie pozostawił z zakresu wymowy kościelnej, to obszerny teoretyczny traktat dla kaznodziejów, który doskonale pokrywa się z praktyką Zawieszki. Wydany w 1607 r. Monotessaron Evangelicum ${ }^{60}$ obejmuje zagadnienia z zakresu retoryki i sposobów interpretacji Pisma Świętego.

57 Supplantator - oszust, ten który oszukuje; to etymologia ludowa imienia. Jej biblijne źródło znajdujemy w Księdze Rodzaju: „A wtedy Ezaw: „Nie darmo dano mu imię Jakub! Dwukrotnie mnie już podszedł: pozbawił mnie mego przywileju pierworodztwa, a teraz odebrał za mnie błogosławieństwo!«” (Rdz 27, 36). Prawdziwe znaczenie to "ten którego Jahwe osłania”. O etymologii ludowej imienia (zob. P. Cz. Bosak, Leksykon wszystkich postaci biblijnych, Wydawnictwo Petrus, Kraków 2015, s. 661).

58 Mikołaj z Wilkowiecka, dz. cyt., 320v-321r.

59 Z. Baran, dz. cyt., s. 328-329.

60 S. Lubomlius, Monotessaron Evangelicum, seu Catena Aurea ex quator Evangelistis, totidemque; pene millibus distinctionum connexa, Officina Typographica Bazilii Scalscii, Kraków 1607. 
Lubomlczyk zajął się w nim szczegółowo zagadnieniem wielości i różnorodności sensów biblijnych ${ }^{61}$, osobną część poświęcając rozpoznaniu i zastosowaniu sensów mistycznych Pisma Świętego ${ }^{62}$. Co ważne, właśnie w tej części znajduje się długi passus poświęcony metaforze. Dominikanin pisał wręcz o niezbędności stosowania przez kaznodziejów metafor, z którymi wiązał następujące wartości dla przepowiadania słowa Bożego: necessitas, dignitas, dicendi vis ${ }^{63}$. Konieczność (necessitas) wynika $\mathrm{z}$ tego, że tylko taki sposób mówienia o sprawach duchowych jest w stanie otworzyć ludzkie zmysły na doświadczenie Bożej tajemnicy. Metafora nadaje też wypowiedzi godności (dignitas), rodzaju dostojeństwa należnych Słowu Bożemu i jego eksplikowaniu. W końcu - moc (dicendi vis) metafory. Dominikanin przekonywał, że zapada w pamięć, a jej wielka siła objawia się zarówno w nauczaniu, przekonywaniu, jak i poruszaniu serc odbiorców.

Znamienne jest, że metafora jest u Lubomlczyka właściwie synonimem pojęcia figuratae locutionis oraz poniekąd tożsama $\mathrm{z}$ alegorią, a wszystkie te pojęcia z kolei sprzęgnięte są ściśle z umiejętnością rozpoznawania i stosowania sensów duchowych w interpretacji Pisma Świętego. Stanowisko w tej sprawie, jakie w swym dziele zaprezentował Seweryn z Lubomli, wskazywało kierunek zmian, w którym podążała siedemnastowieczna potrydencka egzegeza katolicka. Choć trudno wyrokować o znajomości i popularności dzieła Lubomlczyka w Polsce, to niewątpliwie jest ono chyba pierwszym na gruncie polskim tak znaczącym świadectwem zmiany kursu w biblijnej egzegezie, a zarazem przenikliwym studium zaprzęgnięcia do tego celu narzędzi retorycznych.

Lubomlczyk kształcił się m.in. na uniwersytetach w Paryżu, Salamance i Segovii, gdzie miał okazję studiować u wybitnych tomistów Domingo Báñeza (spowiednika św. Teresy z Ávila) oraz Bartolomeo Mediny (1527-1580) ${ }^{64}$. Salamanka miała w tamtym czasie także niezwykle silną szkołę teologii mistycznej, zapoczątkowaną przez Franciszka z Osuny - mistrza świętych: Teresy, Jana od Krzyża i Piotra z Alkantary. Lubomlczyk miał też możność zetknąć się w Salamance $\mathrm{z}$ wybitnym augustianinem Ludwikiem z Leonu (Luis de León; 1527-1591), tłumaczem, egzegetą, teologiem i poetą, kolejnym przedstawicielem wielkiej szkoły hiszpańskiego mistycyzmu. W przedmowie do pracy Monotessaron Evangelicum przywołał swoich mistrzów w dziedzinie tomizmu. Na pierwszym miejscu wymienił dominikanina Kajetana de Vio (Caietanus; 1468-1534). Ten wielki teolog i komentator św. Tomasza z Akwinu szczególne miejsce w swych rozważaniach poświęcił pojęciu teorii analogii bytów. Określa się go wręcz mianem klasyka teorii analogii. Dookreślił i nieco zmodyfikował ustalenia św. Tomasza w tym

61 Tamże, s. 137-166. Fragment zatytułowany Sensuum S. Scripturae diversitas et multiplicitas.

62 Tamże, s. 182-186 (De cognitione sensuum mysticorum).

63 Tamże, s. 182 (§ 507).

64 R. Świętochowski, Szkolnictwo teologiczne dominikanów, s. 269. 
zakresie, wyznaczając kierunek, w jakim tomiści podążali w kolejnych wie$\mathrm{kach}^{65}$.

To przede wszystkim dominikańscy tomiści, a wśród nich Lubomlczyk, rozpowszechnili pojęcie teologii „analogicznej”, w której „przyjmuje się uczestnictwo stworzeń w doskonałościach Stwórcy i relację podobieństwa; odrzuca się bezpośrednią wiedzę o Bogu, a przyjmuje pośrednią wiedzę przez stworzenia"66. Kierunek interpretacji biegnie tam od stworzeń do Boga, a nie odwrotnie. Z takiej perspektywy metafora jest już nie tylko figurą retoryczną, ale kluczowym narzędziem, służącym poznaniu duchowych wykładni Pisma Świętego. Być może u Kajetana szukać można źródeł teologicznych poglądów, które pozwoliły Lubomlczykowi $\mathrm{z}$ takiej perspektywy opisać retoryczne narzędzia oraz ich zastosowanie w interpretacji Biblii i kaznodziejstwie ${ }^{67}$.

Tak konsekwentnie ukształtowana twórczość Zawieszki zasługuje na uwagę tym bardziej, iż próby podobnego sposobu formowania zbiorów kazań spotykamy dopiero po trzydziestu latach. Pierwszym po Zawieszce, u którego konceptystyczny tytuł znalazł zastosowanie w idei i konstrukcji zbioru, był Jacek Liberiusz. Choć trzeba dodać, że tytuł jego dzieła spełnia tę rolę w porównaniu z tymi u Leopolity w minimalnym stopniu. W 1650 r. u jego zbiór kazań maryjnych Gospodyni nieba i ziemie najświętsza Panna Maryja dwudziesta kazań na hymn kościelny „O gloriosa Domina” etc. po różnych w Krakowie kościołach. Tytuł, jakim Liberiusz określił w nim Maryję (Gospodyni/Domina) znalazł rozwinięcie przynajmniej w części kazań. Dodatkowo thema każdego pochodziło z pieśni przywołanej w tytule O gloriosa Domina, a samo kazanie wyjaśniało je i rozwijało. Kolejne fragmenty pieśni nie posiadały prawie wcale potencjału do interpretacji mistycznej, dlatego nawet jeśli takowa się pojawiała, to jej źródłem nie była O gloriosa Domina.

$\mathrm{O}$ wiele bardziej w strukturę zbioru wnika tytuł następnego tomu Liberiusza, również zawierającego kazania maryjne, Gwiazda Morska, najświętsza Panna Maryja trzydziestą kazań na hymn Ave Maris Stella po różnych w Krakowie kościołach zalecona (1670). Podobnie jak we wcześniejszym zbiorze bazę stanowił

65 Znawca zagadnienia M.A. Krąpiec zwrócił uwagę, iż „Zarówno komentatorzy św. Tomasza z epoki renesansu, tomizmu w w. XVI i XVII, jak i współcześni autorzy [...], w ogólnych zarysach nie wychodzą poza kajetanowskie schematy analogii. [...] wszyscy argumentują z pozycji ustalonych przez Kajetana w dziełku De nominum analogia" (M.A. Krąpiec, Teoria analogii bytu, Wydawnictwo Towarzystwa Naukowego KUL, Lublin 1959, s. 186).

66 B. Mikołajczak, Analogia w teologii, [w:] Encyklopedia katolicka, t. 1, red. F. Gryglewicz, R. Łukaszyk, Z. Sułowski, Lublin 1973, kol. 507.

67 Warto odnotować, że w prowincji ruskiej dominikanów, gdzie kształcił się i wiele lat przebywał Zawieszko, uczenie teologii bazowało nie tylko na samym tekście Summy św. Tomasza, ale posługiwano się również podręcznikami komentatorów. Na początku XVII w. były to przede wszystkim komentarze Tomasza de Vio. Zob. R. Świętochowski, Szkolnictwo teologiczne dominikanów, s. 219. 
hymn, którego fragmenty inicjowały kolejne kazania. Tytuł nadany Maryi, Stella Maris, był też swoistym spoiwem zbioru i raz po raz powracał. Jednak ani jeden, ani drugi tom Liberiusza nie wyrażał, tak jak to mamy u Zawieszki, konsekwentnej mistycznej wykładni tytułu.

W 1667 r. Kazimierz Jan Wojsznarowicz wydał tom Dom madrości siedmia kolumnami wsparty w kościele Chrystusowym siedmia uroczystościami Panny Przenaświętszej Maryi ozdobiony (Liberiusz aprobował ten zbiór do druku). Siedem świąt maryjnych (po pięć kazań każde) to kolejnych siedem tytułowych kolumn. Zastosowana metafora przekłada się tutaj jednak tylko na konstrukcję tomu.

Przykładów takich zbiorów na tle ilości produkcji kaznodziejskiej nie ma wcale wiele $^{68}$. Takie zaś, w których tytułowa metafora wnika tak głęboko i konsekwentnie w strukturę, język i obrazowanie całego zbioru, jak to jest u Zawieszki, spotykamy dopiero w XVIII w. Za Dorotą Gostyńską, która analizowała rolę metafory w tworzeniu konceptów, można powiedzieć, iż: „Metafora jest więc, w tym znaczeniu, nie celem twórczych zabiegów, lecz ich początkiem"ø9. W kaznodziejskich pracach, o których mowa, tytułowa metafora staje się zaledwie przesłanką właściwego konceptu, który znajduje rozwinięcie w całym zbiorze.

Przykładami takich dzieł są: Jana Damascena Kalińskiego Proces duszy niepokutujacej przeciwko kaznodziejom, spowiednikom itd. przed strasznym trybunatem boskim wyprowadzony albo kazania na Adwent i pasyje postne (1726), Adriana Serjewicza Zapłata zaciagnionego Adamowego na naturę ludzka dlugu przez Jezusa Chrystusa przy Męce swojej wypetniona, to jest kazania o Męce Pańskiej na pasyjach piatkowych $w$ Samborze miane [...] (1727), Onufrego od Najświętszego Sakramentu Nowy Aaron Nazareński Jezus [...] światu ogłoszony (1730) oraz Różdżka Aaronowa [...] Królowa Maryja Panna [...] kazaniami wysławiona (1732), Adriana Serjewicza Dyjalog albo komedyja Męki Jezusowej w siedmiu scenach lub kazaniach reprezentowana i zgromadzonemu słuchaczowi na pasyjach wtorkowych w Lublinie ogłoszona, czy Antoniego Węgrzynowicza Melodyja św. Kazimierza królewicza polskiego albo pieśni „Omni die” etc. Dnia każdego etc. O Najświętszej Pannie Maryi kazaniami chwałę Najświętszej Panny i oraz potrzebne nauki chrześcijańskie zamykającemi przyozdobiona (1704).

Szczególną grupę stanowią zbiory kazań obejmujące cały liturgiczny cykl roczny niedzielny i świąteczny. Reprezentują ją zaledwie dwaj autorzy, obaj to refor-

68 Wymienić tu można jeszcze przykłady o wiele późniejsze: Tomasza Bohdanowicza, Trąba Nowego testamentu przy okropnej ruin krwawych całego świata tragedyjej słodkobrzmiącym dzieł heroicznych świętych Pańskich dźwiękiem serca wiernych strapione różnemi cieszq̨ca kazaniami (1716), Antoniego Czerniewskiego, Strzały Jonaty, słowa Boskie nigdy się nie powracajace bez zbawiennego pożytku pod zaszczytem sapieżyńskiej strzały w niedzielnych kazaniach [...] (1728) czy Antoniego Szyrmy Rok skarbowy dzieł Pańskich niedzielnymi kazaniami ogłoszonych (1722).

69 D. Gostyńska, Retoryka iluzji. Koncept w poezji barokowej, Wydawnictwo IBL PAN, Warszawa 1991, s. 113. 
maci: Michał Łosiowic i wspomniany już Antoni Węgrzynowicz. Łosiowic taką próbę podjął w zbiorach Rezydencyja Pana nad Pany i Świętego nad świętemi albo kazania o tajemnicach, naukach i czynach Chrystusa Pana [...] (1713) oraz Rezydencyja przyjaciół i stug Pana nad Pany abo kazania na uroczystości Świętych Pańskich $w$ rezydencyi majestatów i panów polskich czynione, tom wtóry (1713). W przypadku Antoniego Węgrzynowicza zaś, podobnie jak u Zawieszki, wszystkie zbiory kazań mają charakter konceptystyczny. Prócz zbiorów kazań maryjnych (Melodyja św. Kazimierza \{1704\}, Alphabetum Immaculatae Conceptionis SS. Virginis Mariae $\{1710\}$, Syllabus Marianus $\{1717\})$ był reformat autorem trzech zbiorów kazań niedzielnych (Kazań niedzielnych księga pierwsza to jest siedm trąb z Objawienia Jana Świętego przeciwko siedmiom głównym grzechom napisane $\{1708\}$; Kazań niedzielnych księga wtóra albo siedm kolumn domu pobożności, to jest o siedmiu cnotach chrześcijańskich \{1713\}; Kazań niedzielnych księga trzecia albo nauki o czterech rzeczach ostatecznych przez całoroczne niedziele rozłożona \{1714\}) i jednego kazań świątecznych (Nuptiae Agni, Gody Baranka Apokaliptycznego albo kazania na uroczyste święta P[ana] Jezusowe, Najświętszej Panny i Świętych Bożych napisane $\{1711\})$. Wszystkie one podporządkowane są naczelnej metaforze zawartej w tytule.

Twórczość Zawieszki i Węgrzynowicza klamrą niejako spina barokowe kaznodziejstwo niedzielne i świąteczne o charakterze konceptystycznym. Niezwykłe jest to, że Zawieszko inicjując nowy nurt w polskim kaznodziejstwie, wyprzedzając o kilkadziesiąt lat swoich następców, w sposób tak pełny i konsekwentny wprowadzał te nowe zasady. Jego twórczość to nie jest etap przejściowy. Leopolita rozpoczął nowy rozdział w polskim kaznodziejstwie już w pełni ukształtowany i świadomy sposobu przepowiadania, który wybrał. To, co Jougan określił mianem początków „psującego się smaku estetycznego"7o, wydaje się być raczej świadomym i konsekwentnym sposobem uprawiania nowej metody przepowiadania słowa Bożego.

Przedstawiony tu dorobek kaznodziejski Zawieszki to wstępna próba oglądu jego twórczości. Jednak już na tym etapie zauważyć można wspólny mianownik poszczególnych zbiorów. Określa on zrazem specyfikę jego twórczości, oraz pozwala dostrzec i docenić pionierstwo Leopolity na gruncie kaznodziejstwa konceptystycznego. Poszczególne zbiory i kazania zasługują na szczegółowy ogląd i opracowanie. Tutaj ich problematyka została zaledwie zasygnalizowana.

\section{Bibliografia}

Abramowska Janina, Powtórzenia i wybory. Studia z tematologii i poetyki historycznej, Dom Wydawniczy Rebis, Poznań 1995.

70 A. Jougan, dz. cyt., s. 195. 
Bajda Jerzy, Poczatki teologii kazuistycznej w Europie i $w$ Polsce, w: Dzieje teologii katolickiej w Polsce, red. Marian Rechowicz, t. 2: Od odrodzenia do oświecenia, cz. 1: Teologia humanistyczna, Wydawnictwo Towarzystwa Naukowego KUL, Lublin 1975, s. 269-305.

Baran Zbigniew, Kaznodzieje zakonni kościoła Mariackiego w Krakowie w latach 1594-1772, „Analecta Cracoviensia. Studia Philosophica - Theologica - Iuridica” 1989-1990, t. 21-23, s. 325-351.

Barącz Sadok, Rys dziejów zakonu kaznodziejskiego w Polsce, Nakładem W. Manieckiego, t. 2, Lwów 1861.

Bonawentura z Bagnoregio św., Konferencje o sześciu dniach stworzenia albo oświecenia Kościoła. Wydanie synoptyczne tekstu oryginalnego redakcji A oraz B z przekładem polskim, przekł., red. i wstęp Aleksander Horowski, Wydawnictwo Serafin, Wydawnictwo Unum, Kraków 2008.

Bosak Paweł Czesław, Leksykon wszystkich postaci biblijnych, Wydawnictwo Petrus, Kraków 2015.

Curtius Ernst Robert, Literatura europejska i łacińskie średniowiecze, przekł. i oprac. Andrzej Borowski, Universitas, Kraków 1997.

Estreicher Karol, Bibliografia polska, t. 21, Drukarnia Uniwersytetu Jagiellońskiego, Kraków 1906.

Gostyńska Dorota, Retoryka iluzji. Koncept w poezji barokowej, Instytut Badań Literackich PAN, Warszawa 1991.

Jocher Adam, Obraz bibliograficzno-historyczny literatury i nauk w Polsce od wprowadzenia do niej druku po rok 1830 włącznie, Drukarnia Uniwersytetu Jagiellońskiego, t. 2, Wilno 1842.

Jougan Alojzy, Homilie polskie od czasów najdawniejszych po dobę obecną. Szkice bibliograficzne i krytyczne, Drukarnia katolicka Józefa Chęcińskiego, Lwów 1902.

Kitowicz Jędrzej, Opis obyczajów za panowania Augusta III, wstęp M. Dernałowicz, Państwowy Instytut Wydawniczy, Warszawa 1985.

Kłoczowski Jerzy, Wielki zakon XVII-wiecznej Rzeczypospolitej u progu swego rozwoju. Dominikanie polscy w świetle wizytacji generalnej z lat 1617-19, „Nasza Przeszłość"1973, t. 39, s. 103-180.

Kłoczowski Jerzy, Wielki zakon XVII-wiecznej Rzeczypospolitej u progu swego rozwoju, [w:] Jerzy Kłoczowski, Polska prowincja dominikańska w średniowieczu i Rzeczypospolitej Obojga (Wielu) Narodów, W Drodze, Poznań 2008.

Kolbuszewski Karol, Postyllografia polska XVI i XVII wieku, Nakładem Polskiej Akademii Umiejętności, Kraków 1921.

Krąpiec Mieczysław, Analogia: II. W filozofii klasycznej, w: Encyklopedia katolicka, t. 1, red. Feliks Gryglewicz, Romuald Łukaszyk, Zygmunt Sułowski, Towarzystwo Naukowe KUL, Lublin 1973, kol. 492-497.

Krąpiec Mieczysław Albert, Teoria analogii bytu, Wydawnictwo Towarzystwa Naukowego KUL, Lublin 1959. 
Kuran Magdalena, Polska religijność pasyjna w świetle kazań wielkopiątkowych (17021732) z biblioteki klasztory reformatów $w$ Zakliczynie, w: Miscellanea literackie i teatralne (od Kochanowskiego do Mrożka). Profesorowi Janowi Okoniowi przez przyjaciót i uczniów na 70. urodziny zebrane, cz. 1, red. Krystyna Płachcińska i Michał Kuran, Wydawnictwo Uniwersytetu Łódzkiego, Łódź 2010.

Leopolita [Zawieszko] Gabriel, Historyja o Jonaszu dla rozmyślania nadroższej Męki Pana Jezusowej, Jan Szeliga, Lwów 1618.

Leopolita [Zawieszko] Gabriel, Iustus iudex ex iustissimi iudicis Jesu Christi, omnibus iudicibus christianis, ad imitandum propositus, In suburbio Jaworoviensi, ad Sanctum Nicolaum [Leopolis] 1615.

Leopolita [Zawieszko] Gabriel, Księgi ćwiczenia chrześcijańskiego, Na Przedmieściu Jaworowskiem u S. Mikołaja [Jaworów] 1611.

Leopolita [Zawieszko] Gabriel, Oratorium pałaczu duchownego, Na Przedmieściu Jaworowskim przy Kościele św. Mikołaja [Jaworów] 1619.

Leopolita [Zawieszko] Gabriel, Przysmaki duchowne, gorczyca i kwas, Na Przedmieściu Jaworowskiem u Ś. Mikołaja [Jaworów] 1619.

Leopolita [Zawieszko] Gabriel, Wąż miedziany albo rozmyślanie nadroższej Męki Syna Bożego z wizerunku węża miedzianego, Jan Szeliga, Lwów 1618.

Leopolita [Zawieszko] Gabriel, Źwierciadło pokutujących. Z przykładów Ś[więtej] $M[$ arii] Magdaleny uczynione. Nie rozpaczajcie wy, co więc Boga gniewacie, [Jan Szeliga], Lwów 1618.

Lubomlczyk Seweryn, Monotessaron Evangelicum, seu Catena Aurea ex quator Evangelistis, totidemque; pene millibus distinctionum connexa, Officina Typographica Bazilii Scalscii, Kraków 1607.

Mikołaj z Wilkowiecka, Flores sermonum in Evangelia Dominicalia post festum Sanctissimae Trinitatis [...], Matheus Gariuoliu, Kraków 1586.

Mikołajczak Bolesław, Analogia: III. Analogia w teologii, [w:] Encyklopedia katolicka, t. 1, red. Feliks Gryglewicz, Romuald Łukaszyk, Zygmunt Sułowski, Towarzystwo Naukowe KUL, Lublin 1973, kol. 498-509.

Nowowieyski Felicjan, Phoenix decoris et ornamentis, provinciae Poloniae, S. Ordinis Praedicatorum [...] redivivus in magnanimis viris, sanctitate vitae, scientiae et eruditione [...], Drukarnia Akademicka, Poznań 1751.

Poniński Stefan, Król nieba i ziemi Chrystus Zbawiciel kazaniami na uroczyste swoje święta [...] wysławiony, Collegium Societatis Jesu, Poznań 1725.

Rychłowski Franciszek, Kazania na święta Panny Przenaświętszej z różnych doktorów i autorów napisane, Kraków 1667.

Rychłowski Franciszek, Na dzień Niepokalanego Poczęcia Panny Przenajświętszej kazanie wtóre (1667), oprac. Wiesław Pawlak i Barbara Niebelska-Rajca, w: Umyst stateczny i w cnotach gruntowny. Prace edytorskie dedykowane pamięci Profesora Adama Karpińskiego, red. Radosław Grześkowiak, Roman Krzywy, Wydział Polo- 
nistyki Uniwersytetu Warszawskiego, Warszawa 2012, „Studia o literaturze dawnej", t. 1, s. 159-183.

Siarczyński Franciszek, Obraz wieku panowania Zygmunta III króla polskiego i szwedzkiego [...], cz. 2, Józef Schnayder, Lwów 1828.

Skwara Marek, O tytułach polskich kazań pogrzebowych z XVII wieku, w: Dzieło literackie i książa w kulturze, red. Ireneusz Opacki przy współudziale Bożeny Mazurkowej, Wydawnictwo Uniwersytetu Śląskiego, Katowice 2002, s. 436-445.

S[obieszczański]F[ranciszek] M[aksymilian], Leopolita (Gabryjel) Zawieszko, w: Encyklopedia powszechna, t. 16, Nakład, druk i własność S. Orgelbranda, Księgarza i Typografa, Warszawa 1864, s. 896-897.

Świętochowski Robert, Początki dominikańskiej prowincji ruskiej (1596-1602), „Prawo Kanoniczne" 1980, t. 23, nr 1-2, s. 51-82.

Świętochowski Robert, Szkolnictwo teologiczne dominikanów, w: Dzieje teologii katolickiej w Polsce, red. Marian Rechowicz, t. 2: Od odrodzenia do oświecenia, cz. 2: Teologia neoscholastyczna i jej rozwój $w$ akademiach i szkołach zakonnych, Towarzystwo Naukowe KUL, Lublin 1975, s. 213-285.

Węgrzynowicz Antoni, Syllabus Marianus syllabarum consonantium alia discursus concionatorii in titulos B. V. Mariae a syllabis initiatos [...], Lwów 1717.

Wujek Jakub, Biblia w przekładzie księdza Jakuba Wujka $z 1599$ r. Transkrypcja typu „B” oryginalnego tekstu z XVI w. i wstępy ks. Janusz Frankowski, Oficyna Wydawnicza „Vocatio”, Warszawa 2000.

Magdalena Kuran

\title{
Twórczość dominikanina Gabriela Zawieszki Początki konceptyzmu w polskim kaznodziejstwie
}

\author{
Streszczenie
}

Artykuł przedstawia twórczość dominikańskiego kaznodziei Gabriela Zawieszki (? - 1649). Każdy z jego sześciu zbiorów kazań podporządkowany jest tytułowej metaforze, która (mniej lub bardziej) wyznacza kształt inwencyjny i kompozycyjny poszczególnych tomów, pojedynczych kazań i argumentów. Leopolita jako pierwszy polski kaznodzieja tak świadomie i szeroko zastosował koncept w kazaniach i całych zbiorach, łącząc go w wielowymiarowym wykorzystaniem w egzegezie sensu duchowego. Podobny sposób formowania zbiorów kazań spotykamy w Polsce dopiero w drugiej połowie XVII wieku.

Słowa kluczowe: kaznodziejstwo dominikańskie; kaznodziejstwo XVII wieku; konceptyzm; alegoria; alegoreza 


\section{The work of the Dominican Gabriel Zawieszko The beginnings of conceptism in polish preaching}

Summary

The article presents the work of the Dominican preacher Gabriel Zawieszko (? - 1649). Each of his six collections of sermons is subordinated to the title metaphor, which (more or less) determines the inventional and compositional shape of individual volumes, individual sermons and arguments. Leopolita as the first Polish preacher so consciously and extensively applied the concept to sermons and entire collections, combining it with the exegesis of spiritual sense (sensus misticus). A similar way of forming collections of sermons is found in Poland only in the second half of $17^{\text {th }}$ century.

Keywords: Dominicans; baroque preaching; conceitism in polish preaching

Dr Magdalena Kuran - adiunkt w Zakładzie Dydaktyki Języka i Literatury Polskiej UŁ. Autorka książki o szesnastowiecznym kaznodziejstwie (Retoryka jako narzędzie perswazji w postyllografii polskiej XVI wieku (na przykładzie „Postylli katolicznej”Jakuba Wujka). Zajmuje się głównie literaturą renesansu (Jakub Wujek, Mikołaj Rej, Mikołaj Sęp-Szarzyński) i baroku (Antoni Węgrzynowicz, Gabriel Zawieszko, Ignacy K. Herko, Stefan Poniński). Główne obszary zainteresowań to kaznodziejstwo staropolskie (szczególnie późnobarokowe), piśmiennictwo zakonne, retoryka, alegoria i alegoreza. 